ARTICLE

Received 1 Jul 2013 | Accepted 23 Sep 2013 | Published 23 Oct $2013 \quad$ DOl: 10.1038/ncomms3657

\title{
Platelets protect from septic shock by inhibiting macrophage-dependent inflammation via the cyclooxygenase 1 signalling pathway
}

Binggang Xiang ${ }^{1}$, Guoying Zhang ${ }^{1}$, Ling Guo ${ }^{2}$, Xiang-An Li ${ }^{1,2}$, Andrew J. Morris ${ }^{1}$, Alan Daugherty ${ }^{1}$, Sidney W. Whiteheart ${ }^{3}$, Susan S. Smyth ${ }^{1,4} \&$ Zhenyu $\mathrm{Li}^{1}$

Although it has long been known that patients with sepsis often have thrombocytopenia and that septic patients with severe thrombocytopenia have a poor prognosis and higher mortality, the role of platelets in the pathogenesis of sepsis is poorly understood. Here we report a protective role of platelets in septic shock. We show that experimental thrombocytopenia induced by intraperitoneal injection of an anti-glycoprotein Ib $\alpha$ monoclonal antibody increases mortality and aggravates organ failure, whereas transfusion of platelets reduces mortality in lipopolysaccharide-induced endotoxemia and a bacterial infusion mouse sepsis model. Plasma concentrations of proinflammatory cytokines TNF- $\alpha$ and IL- 6 are elevated by thrombocytopenia and decreased by platelet transfusion in septic mice. Furthermore, we identify that platelets protect from septic shock by inhibiting macrophagedependent inflammation via the COX1/PGE $/$ EP4-dependent pathway. Thus, these findings demonstrate a previously unappreciated role for platelets in septic shock and suggest that platelet transfusion may be effective in treating severely septic patients.

\footnotetext{
${ }^{1}$ Division of Cardiovascular Medicine, Department of Internal Medicine, Saha Cardiovascular Center, University of Kentucky, Lexington, Kentucky 40536, USA. ${ }^{2}$ Department of Pediatrics, University of Kentucky, Lexington, Kentucky 40536, USA. ${ }^{3}$ Department of Molecular and Cellular Biochemistry, University of Kentucky, Lexington, Kentucky 40536, USA. ${ }^{4}$ Veterans Affairs Medical Center, Lexington, Kentucky 40536, USA. Correspondence and requests for materials should be addressed to Z.L. (email: zhenyuli08@uky.edu).
} 
$\mathrm{P}$ latelets have a central role in physiological haemostasis by preventing excess bleeding, but are also involved in pathologic arterial thrombosis. Emerging evidence suggests that platelets are also critical components of the immune system $^{1,2}$. Platelets are activated in patients with systemic inflammation and sepsis, resulting in their sequestration within microcirculation and thrombocytopenia ${ }^{3,4}$. Severe thrombocytopenia in septic patients is associated with adverse outcome and high mortality ${ }^{5-7}$. Platelets regulate inflammation and sepsis through multiple mechanisms. Platelets express a lipopolysaccharide (LPS) receptor, Toll-like receptor-4, which contributes to thrombocytopenia through a neutrophil-dependent pulmonary sequestration in response to PPS $^{8-10}$. Platelets also interact with other leukocytes, including monocytes ${ }^{11,12}$. Interaction of activated platelets with monocytes induces nuclear translocation of nuclear factor- $\kappa \mathrm{B}(\mathrm{NF}-\kappa \mathrm{B})$ and expression of $\mathrm{NF}-\kappa \mathrm{B}$-dependent inflammatory genes ${ }^{13-15}$. In addition to direct interactions with leukocytes, platelets contribute to inflammation and immune progression by releasing cytokines and mediators stored in alpha and dense granules upon stimulation ${ }^{16,17}$.

In the present study, we used LPS-induced endotoxemia model and a bacterial infusion sepsis model through intraperitoneal (i.p.) injection of LPS or an Escherichia coli strain ATCC 25922, respectively, into mice to investigate the effects of experimental thrombocytopenia and platelet transfusion on septic shock. LPS or endotoxin, a component of the outer membrane of Gramnegative bacteria, has an essential role in the pathogenesis of sepsis. LPS administration into mice has become a standard inflammation model and is widely used in sepsis research ${ }^{18}$. Human sepsis is often caused by a single pathogen. The bacterial infusion model introduces a single pathogen into mice in a controlled manner, allowing reproducible infection, which has also been translated to larger animals for the study of systemic and organ-specific haemodynamics. We demonstrate that experimental thrombocytopenia increases mortality and aggravates organ failure, whereas transfusion of platelets reduces mortality in LPS-induced endotoxemia and $E$. coli ATCC 25922-induced sepsis. Our data reveal an important new role for platelets in sepsis and define a mechanism by which platelets protect from septic shock.

\section{Results}

Thrombocytopenia exacerbates septic shock and organ failure. To establish a role of platelets in sepsis-associated inflammation, we induced thrombocytopenia in mice by i.p. injection of a rat antimouse GPIb $\alpha$ monoclonal antibody. Four hours after injection of the antibody, platelet counts were decreased by $90 \%$ (Fig. 1a). Platelet counts were not altered by injection of an isotype-matched rat IgG control. We then compared survival rates between the IgG-treated and thrombocytopenic mice after LPS challenge. Unexpectedly, thrombocytopenic mice had a significantly greater mortality rate than the mice administered with control IgG (Fig. 1b). All thrombocytopenic mice died within $36 \mathrm{~h}$ after LPS challenge. In contrast, none of the mice treated with control IgG died within $36 \mathrm{~h}$ after challenge by LPS. Lethality in sepsis is associated with organ failure. Thus, we examined the effects of thrombocytopenia on liver function in mice challenged with LPS. Plasma concentrations of liver enzymes, alanine aminotransferase and aspartate aminotransferase that are released into the circulation on injury and death of liver cells, respectively, were significantly higher in plasma from antimouse GPIb $\alpha$ monoclonal antibody-treated mice than those that received control IgG (Fig. 1c,d). Lactate dehydrogenase (LDH) is an enzyme found in many tissues, including the liver and heart, and may be released into plasma with hepatic and myocardial damage.
Accordingly, plasma LDH concentration was higher in the thrombocytopenic mice than that of control mice (Fig. 1e). Creatine kinase (CK), an enzyme expressed by various tissues and cell types, can be elevated in plasma as a consequence of muscle injury or renal failure due to reduced clearance. Plasma CK concentrations were much higher in thrombocytopenic mice than in IgG-treated mice (Fig. 1f). Together, these results demonstrate that thrombocytopenia exacerbates tissue injury associated with sepsis.

Thrombocytopenia does not cause inflammatory haemorrhage. Previous studies reported that inflammation caused life-threatening haemorrhage during thrombocytopenia ${ }^{19,20}$. In those studies, the anti-GPIb $\alpha$ monoclonal antibody was injected intravenously or retro-orbitally, which resulted in a lowering of platelet count to $<2.5 \%$ of that of control mice. However, no detectable haemorrhage occurred in the lungs (Fig. 1g,h) from mice in which thrombocytopenia was induced by i.p. injection of the anti-GPIb $\alpha$ antibody. In addition, red blood cell counts and haemoglobin concentrations were not significantly different between IgG-treated mice and the anti-GPIb $\alpha$ antibody-treated mice after LPS injection. Thus, inflammatory haemorrhage did not appear to account for the higher mortality rates with LPS in mice rendered thrombocytopenic by i.p. injection of the anti-GPIb $\alpha$ antibody.

Thrombocytopenia aggravates inflammatory response to LPS Endotoxemia increases production of endogenous cytokines, including tumor necrosis factor- $\alpha$ (TNF- $\alpha$ ) and interleukin (IL)6 , which have important roles in the development of disseminated intravascular coagulation, acute respiratory distress syndrome and septic shock ${ }^{21-24}$. Therefore, we investigated whether platelets protect from endotoxemia by altering expression of these cytokines. Indeed, LPS elevated plasma levels of TNF- $\alpha$ and IL-6, and the effect was amplified in thrombocytopenic mice (Fig. 2a,b). These results suggest that platelets normally inhibit endotoxemia-induced cytokine production. Macrophages are a major source of TNF- $\alpha$ in vivo $22,25,26$. Therefore, we hypothesize that platelets protect from septic shock by attenuating macrophage-dependent inflammatory response, thereby decreasing concentrations of these proinflammatory cytokines in plasma. We further hypothesize that platelet depletion increases TNF- $\alpha$ and IL-6 production by reducing a macrophage inhibitor factor(s). If these hypotheses are correct, then thrombocytopenia should have no effect on LPS-induced increases in plasma TNF- $\alpha$ and IL- 6 levels in the mice lacking macrophages. Macrophages were depleted by retro-orbital injection of liposomal clodronate. Macrophage depletion was confirmed by detecting peripheral monocyte concentration by flow cytometry with an Alexa Fluor 488-labelled anti-CD115 monoclonal antibody. Monocyte concentration was reduced by $>95 \%$ (Fig. $2 c, d$ ). As expected, plasma TNF- $\alpha$ concentrations were significantly decreased in macrophage-depleted mice challenged with LPS compared with the mice injected with control liposomes (Fig. 2e). The increase in plasma TNF- $\alpha$ observed in thrombocytopenic mice was absent when macrophages were predepleted.

Macrophages do not appear to be a major source of IL-6 production early after LPS challenge, because depletion of macrophages did not alter plasma IL-6 concentrations until more than $4 \mathrm{~h}$ after injection of LPS (Fig. $2 \mathrm{f}$ ). At $8 \mathrm{~h}$ after injection of LPS, depletion of macrophages decreased plasma IL-6 concentrations, suggesting that macrophages contribute to plasma IL-6 production at later stages of endotoxemia. Thrombocytopenia increased plasma IL-6 concentrations in control 

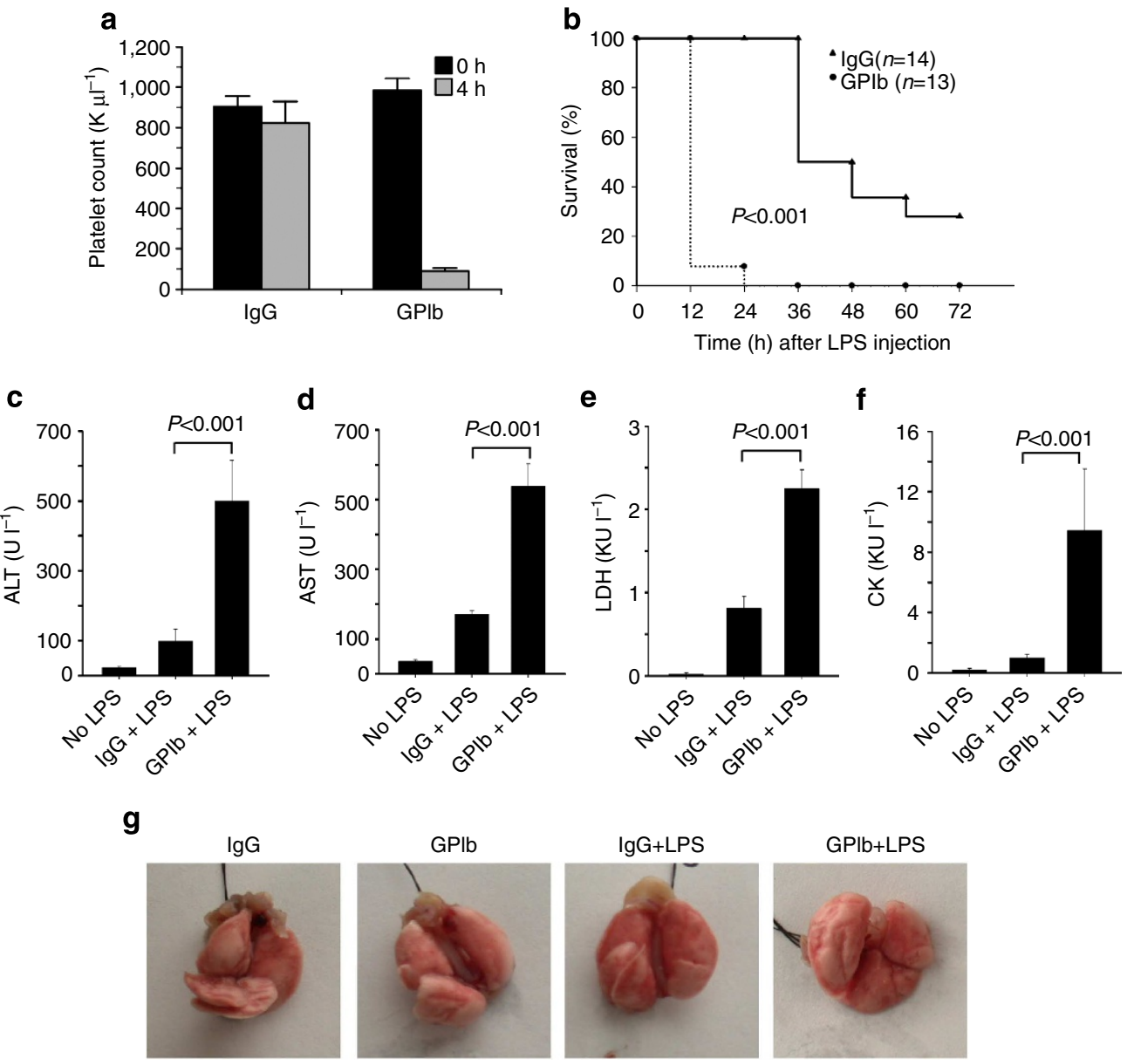

h $\lg G$
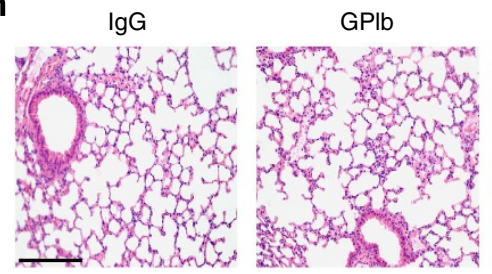

$\lg \mathrm{G}+\mathrm{LPS}$

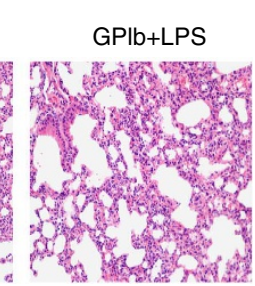

Figure 1 | Depletion of platelets in mice enhances mortality and worsens organ failure induced by LPS. (a) C57BL/ 6 mice were injected with $4 \mu \mathrm{gg} \mathrm{g}^{-1}$ of body weight of a rat antimouse GPIb $\alpha$ monoclonal antibody $(n=7)$ or control rat $\operatorname{lgG}(n=8)$ by i.p. Platelets counts were measured with a HEMAVET HV950FS multispecies haematology analyser before and $4 \mathrm{~h}$ after injection of antibody. Values are means \pm s.d. (b) Mice were then injected with LPS $\left(10 \mathrm{mg} \mathrm{kg}^{-1}\right)$. Survival rate was observed for up to 3 days. P-value was calculated by Wald's test in a discrete time hazard model using version 9.2 of SAS software. (c-f) Eight hours after LPS treatment, plasma from mice receiving anti-GPIb antibody or lgG control were collected and alanine aminotransferase (ALT; $\mathbf{c}$ ), aspartate aminotransferase (AST; $\mathbf{d}), \mathrm{LDH}(\mathbf{e})$ and $\mathrm{CK}(\mathbf{f})$ concentrations in plasma were measured. Values are means $\pm \mathrm{s} . \mathrm{d}$. $(n=4)$. Differences between two groups were assessed using unpaired two-tailed Student's $t$-test. (g,h) Mice were injected i.p. with a rat antimouse GPIb $\alpha$ monoclonal antibody or rat IgG control. After $4 \mathrm{~h}$, mice were injected i.p. with LPS $\left(10 \mathrm{mg} \mathrm{kg}^{-1}\right)$. Fifteen hours after LPS injection, mice were killed and the lungs were collected ( $\mathbf{g}$ ). Sections of lungs were stained with haematoxylin and eosin and images were captured. Scale bar, $0.5 \mathrm{~mm}$ (h).

mice administrated liposomes but had no effect in mice predepleted with macrophages (Fig. 2f). These results demonstrate that platelets inhibit macrophage-derived IL-6 but have no effect on IL-6 production derived from other cells.

Thrombocytopenia exacerbates bacterial sepsis. We further investigated the role of platelets in septic shock using a bacterial infusion sepsis model. C57BL/6J mice were injected with the antiGPIb $\alpha$ monoclonal antibody to deplete platelets. Four hours after injection of the antibody, the mice received i.p. $0.2 \mathrm{ml}$ saline containing $2 \times 10^{7}$ colony-forming unit of E. coli ATCC 25922 per mouse. Thrombocytopenic mice had dramatically higher plasma levels of TNF- $\alpha$ and IL-6 (Fig. 3a,b), and a greater mortality rate compared with the mice administered control IgG (Fig. 3c).

Platelet transfusion protects against septic shock. As platelets inhibited macrophage-derived TNF- $\alpha$ and IL- 6 production, platelet transfusion may reduce in vivo inflammatory response during sepsis, thereby protecting from septic shock. C57BL/6J mice were injected retro-orbitally with washed platelets from the same background $\left(1 \times 10^{9}\right.$ per mouse $)$ immediately after injection 
a

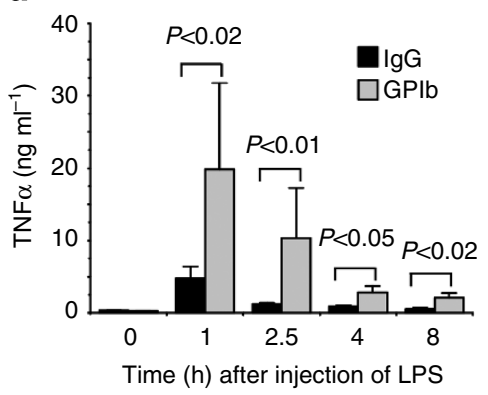

b

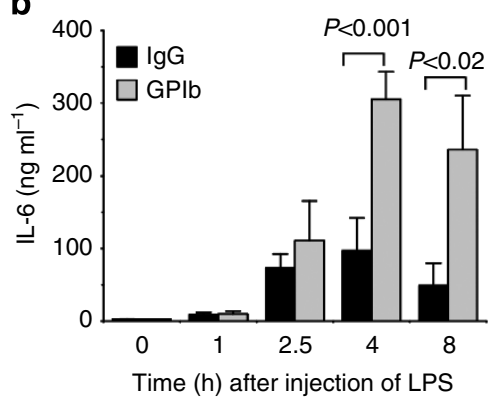

C

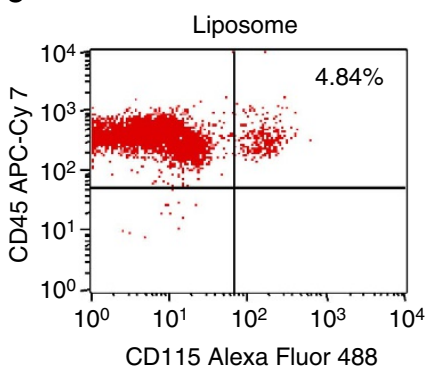

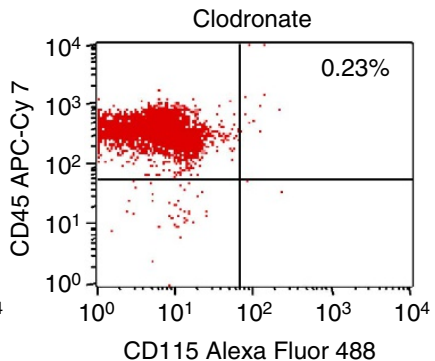

d

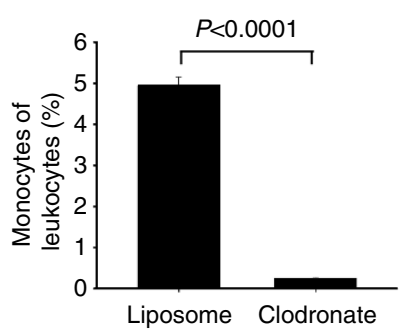

e

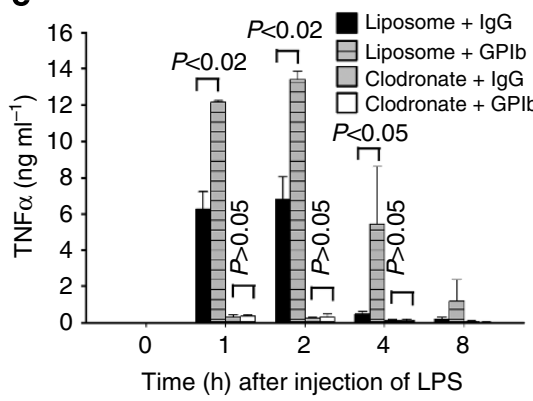

f

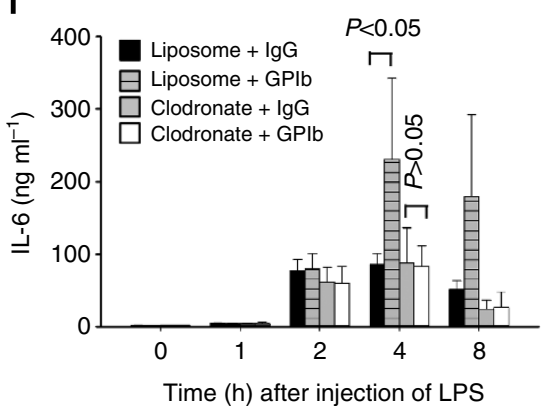

Figure 2 | The effects of thrombocytopenia on plasma TNF- $\alpha$ and IL-6 concentrations. (a,b) Mice were injected i.p. with a rat antimouse GPIb $\alpha$ monoclonal antibody or rat lgG control. After $4 \mathrm{~h}$, the mice were injected i.p. with LPS $\left(10 \mathrm{mg} \mathrm{kg}^{-1}\right)$. Blood was collected from these mice before or at $1,2.5$, 4 and $8 \mathrm{~h}$ after LPS injection. TNF- $\alpha$ (a) and IL-6 (b) concentrations in plasma were measured by an enzyme-linked immunosorbent assay. Values are means \pm s.d. $(n=6)$. Differences between two groups were assessed using unpaired two-tailed Student's t-test. (c,d) Mice were injected retro-orbitally with clodronate $\left(40 \mathrm{mg} \mathrm{kg}^{-1}\right)$ or control liposome. Blood was collected from the mice at $24 \mathrm{~h}$ after injection of clodronate or liposome. Representative flow cytometry plots of monocyte subsets (c) and quantification of monocyte subsets $(\mathbf{d})(n=3)$ are shown. Error bars indicate s.d. Difference was assessed using unpaired two-tailed Student's t-test. (e,f) Mice were injected retro-orbitally with clodronate $\left(40 \mathrm{mg} \mathrm{kg}^{-1}\right)$ or control liposomes at 24 and $4 \mathrm{~h}$ before LPS injection. The mice were also injected i.p. with a rat antimouse GPIb $\alpha$ monoclonal antibody or rat lgG control at $4 \mathrm{~h}$ before LPS injection. Blood was collected before or at 1, 2, 4 and $8 \mathrm{~h}$ after LPS injection, and plasma TNF- $\alpha$ (e) and IL-6 (f) concentrations were measured. Values are means \pm s.d. $(n=5)$. Differences between two groups were assessed using unpaired two-tailed Student's $t$-test.

of LPS (i.p). Injection of $1 \times 10^{9}$ platelet per mouse increased platelet counts by $\sim 25 \%$ (Fig. $4 \mathrm{a}$ ). Plasma TNF- $\alpha$ and IL-6 concentrations following LPS were significantly lower in mice injected with platelets versus saline (Fig. 4b,c). Platelet transfusion also attenuated thrombocytopenia during endotoxemia (Fig. 4a). Platelet transfusion increased the survival rate from $16.0 \%$ to $41.7 \%$ (Fig. $4 \mathrm{~d}$ ) and $6.7 \%$ to $40.0 \%$ (Fig. 4 e), respectively, in LPSinduced endotoxemia model and bacterial infusion sepsis model.

Protection against sepsis by platelets depends on macrophages. To determine whether the protective effect of platelet transfusion on sepsis depends on inhibition of macrophage function, macrophages were depleted by retro-orbital injection of liposomal clodronate. As injection of control liposome increased mortality rate in the LPS-challenged mice, a lower dose of LPS was applied. Depletion of macrophage increased survival rate from $8.33 \%$ to
$50.0 \%$ in response to LPS challenge (Fig. 4f). Transfusion of platelets did not significantly increase the survival rate in the macrophage-depleted mice. These results suggest that the protective effect of platelet transfusion on endotoxemia depends on macrophages.

Platelets inhibit macrophage-derived TNF- $\alpha$ and IL-6. Next, in-vitro experiments were performed to address whether platelets directly inhibit macrophage-derived cytokines in response to LPS. Mouse bone marrow-derived macrophages (BMDMs) were stimulated with LPS in the presence or absence of washed mouse platelets. Although addition of platelets increased TNF- $\alpha$ production from macrophages in response to a low-dose LPS (Fig. 5a), TNF- $\alpha$ production elicited by higher concentrations of LPS was dramatically reduced by addition of platelets (Fig. 5a). Similarly, IL-6 production induced by LPS was reduced by 


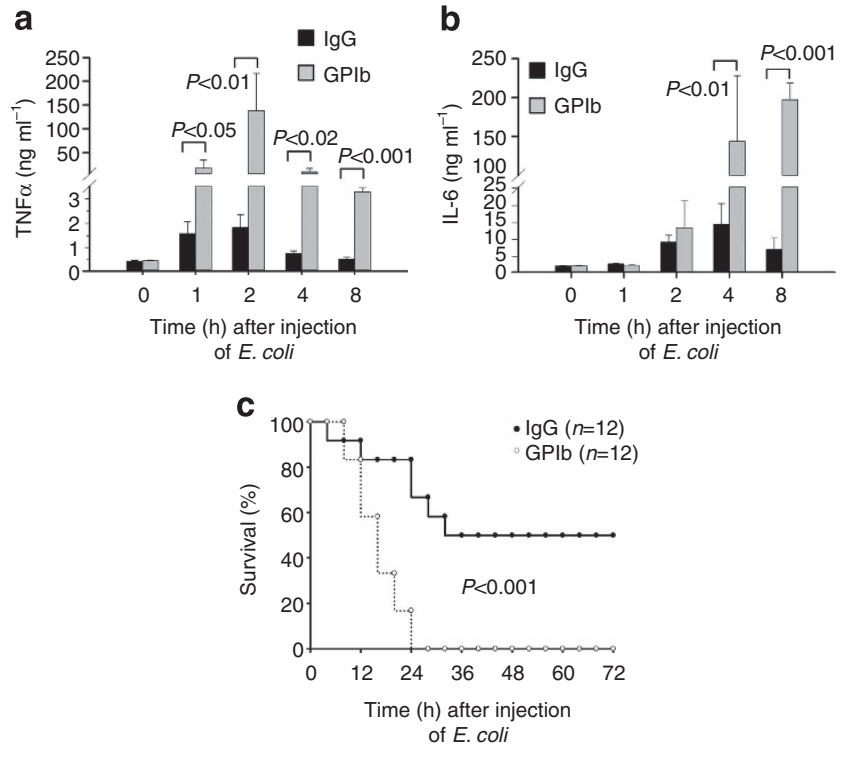

Figure 3 | Platelets inhibit inflammation and protect against septic shock in a bacterial infusion sepsis model. $(\mathbf{a}, \mathbf{b})$ Mice were injected i.p. with a rat antimouse GPIb $\alpha$ monoclonal antibody or rat IgG control. After $4 \mathrm{~h}$, the mice were injected i.p. with $0.2 \mathrm{ml}$ saline containing $2 \times 10^{7}$ colony-forming unit (CFU) of E. coli ATCC 25922 per mouse. Blood was collected from these mice before or at 1, 2, 4 and $8 \mathrm{~h}$ after injection of bacteria. TNF- $\alpha$ (a) and IL-6 (b) concentrations in plasma were measured by enzyme-linked immunosorbent assays. Values are means \pm s.d. $(n=6)$. Differences between two groups were assessed using unpaired two-tailed Student's t-test. (c) C57BL/6 mice were injected i.p. with a rat antimouse GPIb $\alpha$ monoclonal antibody or control rat $\operatorname{lgG}\left(4 \mu g^{-1}\right.$ of body weight). After $4 \mathrm{~h}$, the mice were injected with $0.2 \mathrm{ml}$ saline containing $2 \times 10^{7} \mathrm{CFU}$ of $E$. coli ATCC 25922. Survival rate was observed for up to 3 days. $P$-value was calculated by Wald's test in a discrete time hazard model using version 9.2 of SAS software.

addition of platelets (Fig. 5a). As LPS at $100 \mathrm{ng} \mathrm{ml}^{-1}$ induced maximal TNF- $\alpha$ and IL- 6 production from macrophages, this concentration of LPS was chosen to investigate the mechanism whereby platelets inhibit macrophage-derived TNF- $\alpha$ in the following experiments.

Platelets express the LPS receptor, Toll-like receptor- 4 . To exclude the possibility that inhibition of LPS-induced TNF- $\alpha$ production is due to platelet sequestration of LPS, platelets were incubated with $\mathrm{H}^{3}$-labelled LPS for $2 \mathrm{~h}$ and the amount of radioactivity associated with platelets was measured. Despite the presence of LPS receptor on platelets, radioactivity remained in the supernatant rather than with platelets (Fig. 5b).

Platelet releasates inhibit TNF- $\alpha$ and IL-6 production. To determine whether platelets inhibit macrophage-derived cytokines through direct interaction between platelets and macrophages or by releasing inhibitory factors, platelets were incubated with LPS for $30 \mathrm{~min}$ and then centrifuged. The resulting supernatant containing LPS was added to macrophages. LPS in the presence of platelet releasate elicited less TNF- $\alpha$ and IL- 6 production than did LPS alone (Fig. 5c).

The coagulation system is activated during sepsis, resulting in thrombin generation ${ }^{27,28}$, a physiological platelet agonist. Therefore, during sepsis, platelets are activated not only by LPS but also by physiological agonists such as thrombin. To determine whether platelet activation induced by a physiological agonist has an effect on macrophages, platelets from C57BL/6 mice were stimulated with thrombin and stirred in an aggregometer at $37^{\circ} \mathrm{C}$ for $5 \mathrm{~min}$. Supernatant from the thrombin-stimulated platelets markedly inhibited LPS-induced TNF- $\alpha$ and IL- 6 production by macrophages (Fig. 5c). Thrombin-induced platelet activation and secretion requires $G_{\mathrm{q}}$ signalling ${ }^{29}$. As expected, supernatant of thrombin-stimulated wild-type platelets, but not $G_{\mathrm{q}}$-deficient platelets, inhibited LPS-induced TNF- $\alpha$ production (Fig. $5 \mathrm{~d}$ ). Taken together, these results demonstrate an inhibitory role of platelet activation in LPS-induced TNF- $\alpha$ production by macrophages.

We next examined the effects of platelet releasate on TNF- $\alpha$ production from macrophages induced by serum amyloid A to determine whether platelet activation has a common role in the regulation of macrophage response to inflammatory challenge. Addition of supernatant of thrombin-stimulated platelets reduced serum amyloid A-stimulated TNF- $\alpha$ production by macrophages (Fig. 5e).

The effect of platelet secretion on TNF- $\alpha$ production. Platelets contain two major types of granules: $\alpha$-granules containing soluble and membrane-associated proteins and dense granules containing small molecules such as nucleotides ${ }^{30}$. In response to agonist activation, including LPS, platelets secrete granule content $^{31-33}$. We therefore investigated whether granule releasate contributes to the inhibitory effects of platelets on macrophages. Most components secreted from $\alpha$-granules are proteins ${ }^{16}$ that are sensitive to heating or proteinase $\mathrm{K}$ treatment. However, neither heating (Supplementary Fig. S1a) nor proteinase K (Supplementary Fig. S1b) treatment blunted the inhibitor effects of activated platelet supernatant on TNF- $\alpha$ production by macrophages.

ADP secreted from dense granules has an essential role in platelet activation through its receptor $\mathrm{P}_{2} \mathrm{Y}_{12}$ and $\mathrm{P}_{2} \mathrm{Y}_{1}$ (ref. 34). The addition of the ADP scavenger apyrase did not block the inhibitory effect of platelet releasate on LPS-induced TNF- $\alpha$ production by macrophages (Supplementary Fig. S2a). Furthermore, platelet releasate inhibited LPS-induced TNF- $\alpha$ from macrophages lacking the ADP receptor $\mathrm{P}_{2} \mathrm{Y}_{12}$ (Supplementary Fig. S2b), indicating that ADP is not required for the inhibition of macrophages by platelets. Munc13-4 is critical for cargo release from both $\alpha$ - and dense granules of platelets ${ }^{35}$. Platelet releasates from Unc13d $d^{\text {Iinx }}$ mice that lack Munc13-4 inhibited LPS-induced TNF- $\alpha$ by macrophages (Supplementary Fig. S2c). Taken together, these results suggest that inhibition of macrophagederived TNF- $\alpha$ by platelets is independent of granule cargo release from platelets.

Platelets inhibit TNF- $\alpha$ through the COX1-dependent pathway. Synthesis of $\mathrm{TXA}_{2}$ from cyclooxygenase 1 (COX1) signalling is an important positive feedback mechanism for platelet activation. To determine whether COX1 is involved in platelet inhibition of macrophages, we examined whether aspirin, a COX1 inhibitor, could reverse the inhibitory effect of platelets on macrophages. Pretreatment of platelets with aspirin markedly reversed inhibition of LPS-induced TNF- $\alpha$ production from macrophages by platelet releasates (Fig. 6a). Accordingly, supernatant from thrombin-activated COX1-deficient platelets had less effect than that of wild-type platelets on inhibiting macrophage-derived TNF- $\alpha$ (Fig. 6b). Considering the importance of $\mathrm{TXA}_{2}$ in regulating platelet activation, we asked whether $\mathrm{TXA}_{2}$ synthesized from COX1 signalling is responsible for platelet inhibition on macrophages. Addition of a stable $\mathrm{TXA}_{2}$ analogue, U46619, failed to inhibit LPS-induced TNF- $\alpha$ production by macrophages (Supplementary Fig. S3a). Supernatant from thrombin-stimulated wild-type platelets inhibited LPS-induced TNF- $\alpha$ production by 
a

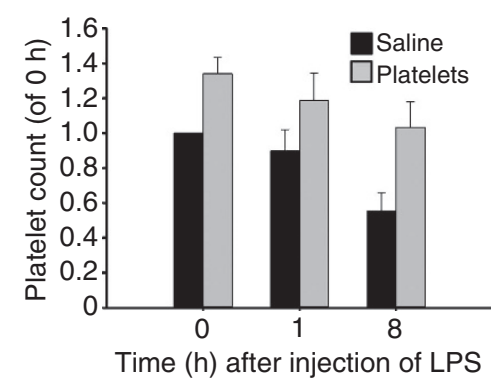

c

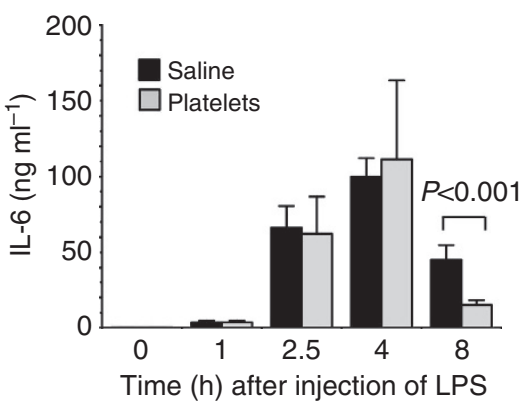

e

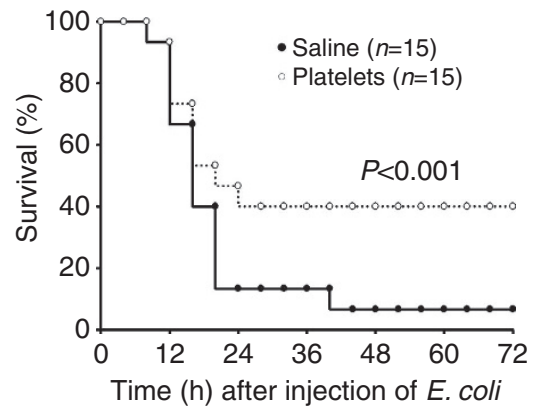

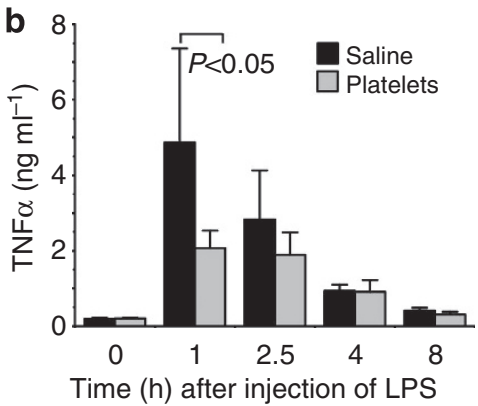

d

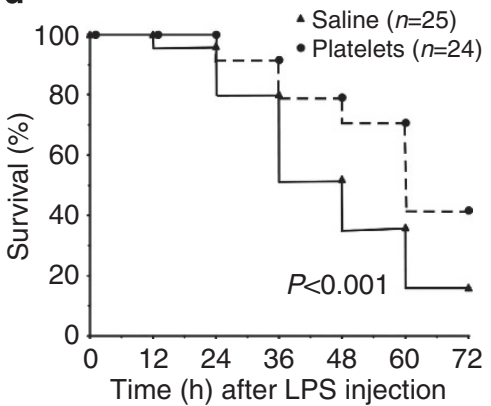

f

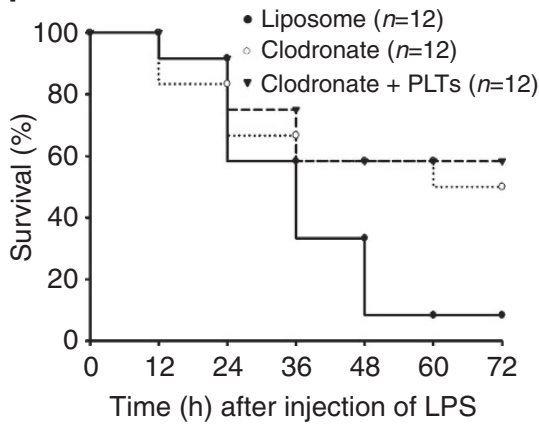

Figure 4 | The effects of platelet transfusion on plasma TNF- $\alpha$ and IL-6 concentrations and mortality in septic animals. (a-c) Mice were injected with LPS i.p. $\left(10 \mathrm{mg} \mathrm{kg}^{-1}\right)$ followed by retro-orbital injection of $1 \times 10^{9}$ platelets in $0.2 \mathrm{ml}$ saline or saline only. Blood were collected before or at $1,2.5,4$ and $8 \mathrm{~h}$ after LPS injection. Platelet counts were measured before or at 1 and $8 \mathrm{~h}$ after LPS injection and expressed as relative to the counts of saline-treated mice before injection of LPS (a). Plasma TNF- $\alpha$ (b) and IL-6 (c) concentrations were measured. Values are means \pm s.d. $(n=5)$. Differences between two groups were assessed using unpaired two-tailed Student's $t$-test. (d) Mice were injected with LPS (10 $\mathrm{mg} \mathrm{kg}^{-1}$ ), immediately followed by retro-orbital injection of $1 \times 10^{9}$ platelets in $0.2 \mathrm{ml}$ saline or saline only. Survival rate was observed for 3 days. $P$-value was calculated by Wald's test in a discrete time hazard model using version 9.2 of SAS software. (e) C57BL/6 mice were injected i.p. with $0.2 \mathrm{ml}$ saline containing $2.5 \times 10^{7}$ colony-forming unit of E. coli ATCC 25922, immediately followed by retro-orbital injection of $1 \times 10^{9}$ platelets in $0.2 \mathrm{ml}$ saline or saline only. Survival rate was observed for up to 3 days. $P$-value was calculated by Wald's test in a discrete time hazard model using version 9.2 of SAS software. (f) Mice were injected retro-orbitally with clodronate or control liposomes at 24 and $4 \mathrm{~h}$ before LPS injection ( $5 \mathrm{mg} \mathrm{kg}^{-1}$ of body weight), immediately followed by retro-orbital injection of $1 \times 10^{9}$ platelets in $0.2 \mathrm{ml}$ saline or saline only. Survival rate was observed for up to 3 days. $P<0.001$ between liposome group and clodronate group; $P>0.2$ between clodronate group injected with saline and clodronate group injected with platelets. $P$-value was calculated by Wald's test in a discrete time hazard model using version 9.2 of SAS software.

macrophages lacking the $\mathrm{TXA}_{2}$ receptor, TP (Supplementary Fig. S3b). Thus, platelet inhibition of macrophage function is likely to be independent of $\mathrm{TXA}_{2}$.

COX1 activation results in the production of many types of prostaglandins. Prostaglandin $\mathrm{E}_{2}\left(\mathrm{PGE}_{2}\right)$ modulates macrophage function and decreases TNF- $\alpha$ and IL- 6 production via its receptors EP1-4 (refs 36,37). LPS and thrombin stimulated $\mathrm{PGE}_{2}$ production in platelets (Fig. 6c), and $\mathrm{PGE}_{2}$ or heated $\mathrm{PGE}_{2}$ inhibited LPS-induced TNF- $\alpha$ production in macrophages (Supplementary Fig. S3c). To determine whether $\mathrm{PGE}_{2}$ is required for platelet inhibition of LPS-induced TNF- $\alpha$ production by macrophages, macrophages were pre-incubated with antagonists of EP1-4. EP4 antagonist, GW62, but not the antagonists for
EP1-3, reversed the inhibitory effect of platelet releasates on LPSinduced TNF- $\alpha$ production from macrophages (Fig. $6 \mathrm{~d}$ ), indicating that platelet inhibition of macrophage function involves the $\mathrm{PGE}_{2} / \mathrm{EP} 4$ pathway.

In agreement with the in-vitro observations, plasma TNF- $\alpha$ and IL-6 levels were higher in LPS-treated C57BL/6 mice injected with COX1-deficient platelets than with platelets from wild-type littermates (Fig. 7a,b). Injection of COX1-deficient platelets failed to protect from LPS-induced septic shock (Fig. 7c). Next, we investigated the role of aspirin on sepsis. We first determined the effective dose of aspirin in inhibiting platelet COX1 activity in vivo. Thrombin-induced $\mathrm{TXA}_{2}$ production was completely abolished in the platelets isolated from mice administrated with 
a
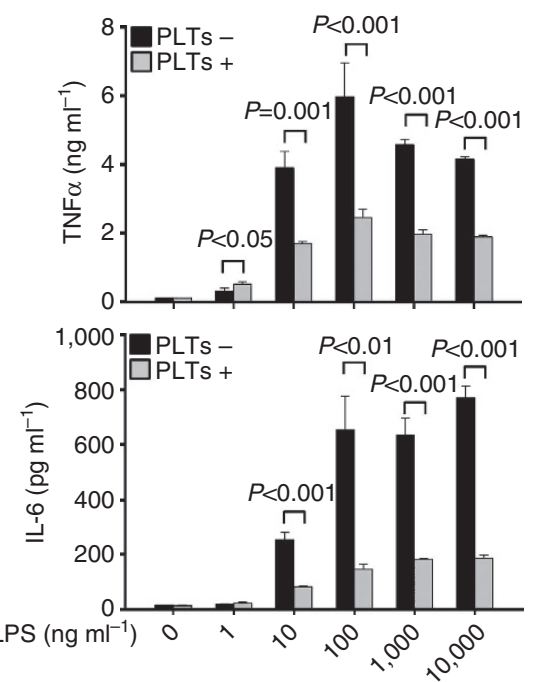

C
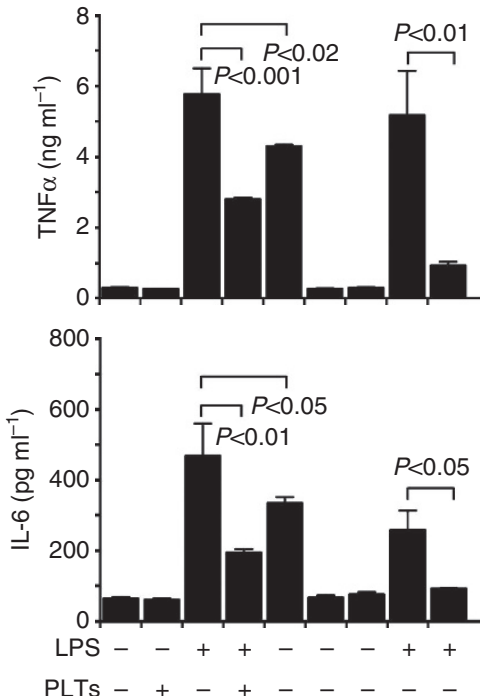

Sup of LPS-

activated PLTs

Throm

Sup of throm-

activated PLTs b

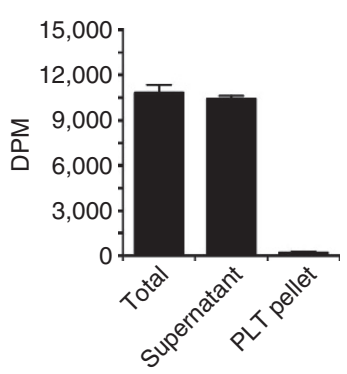

d

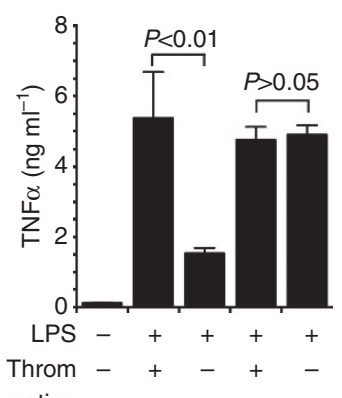

Sup of resting

WT PLTS

Sup of Thromactivated WT PLTs

Sup of resting

$$
\mathrm{Gq}^{-/-} \text {PLTs }
$$

Sup of Thromactivated $\mathrm{Gq}^{-1-} \mathrm{PLTs}$

e

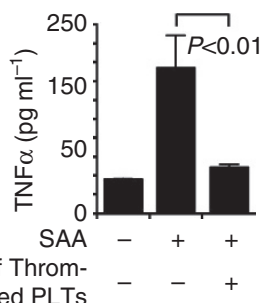

Figure 5 | Platelets or platelet releasates inhibit TNF- $\alpha$ and IL- 6 production induced by LPS in bone marrow-derived macrophages. (a) LPS

$\left(1 \mathrm{ng} \mathrm{ml}{ }^{-1} \sim 10 \mu \mathrm{g} \mathrm{ml}^{-1}\right)$ was added with buffer or washed platelets $\left(3 \times 10^{8}\right.$ per ml) to BMDMs and incubated for $6 \mathrm{~h}$. TNF- $\alpha$ and IL- 6 concentrations in the supernatant were measured. (b) Washed platelets or medium were incubated with ${ }^{3} \mathrm{H}$-LPS $(250 \mathrm{ng} \mathrm{ml}-1)$ at $37^{\circ} \mathrm{C}$ for $2 \mathrm{~h}$ and centrifuged.

Disintegrations per minute (DPM) in medium, platelet pellet or supernatant was measured. (c) LPS (100 ng ml ${ }^{-1}$ ) was added to BMDMs in the presence or absence of platelets $\left(3 \times 10^{8}\right.$ per ml) and incubated for $6 \mathrm{~h}$. Washed platelets $\left(3 \times 10^{8}\right.$ per ml) were also incubated with LPS (100 $\left.\mathrm{ng} \mathrm{ml}{ }^{-1}\right)$ for $30 \mathrm{~min}$ or thrombin (Enzyme Research Laboratories, South Bend, IN, $0.1 \mathrm{U} \mathrm{ml}^{-1}$ ) in aggregometer at $37^{\circ} \mathrm{C}$ for 5 min and centrifuged. The resulting supernatants with LPS were added to BMDMs and incubated for $6 \mathrm{~h}$. LPS plus thrombin (Throm) were added to BMDMs and incubated for $6 \mathrm{~h}$ as a control. TNF- $\alpha$ and IL- 6 concentrations in the supernatant were measured. (d) Washed platelets from $G_{q}$ knockout mice or wild-type littermates were incubated with thrombin in aggregometer at $37^{\circ} \mathrm{C}$ for $5 \mathrm{~min}$ and centrifuged. Supernatants plus LPS were added to BMDMs and incubated for $6 \mathrm{~h}$. (e) Platelets $\left(3 \times 10^{8}\right.$ per ml) were pre-incubated with thrombin in aggregometer at $37^{\circ} \mathrm{C}$ for $5 \mathrm{~min}$ and centrifuged. Serum amyloid A (SAA) $\left(1 \mu \mathrm{g} \mathrm{ml} \mathrm{l}^{-1}\right)$ together with buffer or supernatant from thrombin-stimulated platelets were added to BMDMs and incubated for $6 \mathrm{~h}$. Values are means \pm s.d. $(n=3$ for all). Differences between two groups were assessed using unpaired two-tailed Student's $t$-test.

10 or $25 \mathrm{mg} \mathrm{kg}^{-1}$ of aspirin (Fig. $\left.7 \mathrm{~d}\right)$. Aspirin $\left(25 \mathrm{mg} \mathrm{kg}^{-1}\right)$ pretreated mice had significantly higher plasma TNF- $\alpha$ and IL-6 concentrations than control mice (Fig. 7e,f). Aspirin pretreatment also reduced survival rate in the LPS-induced sepsis model (Fig. 7g). Taken together, these results demonstrate that platelet inhibition of inflammatory responses and LPS-induced TNF- $\alpha$ production from macrophages is dependent on platelet COX1 activity.

\section{Discussion}

Growing evidence indicates that platelets are key effectors in many inflammatory diseases. In sepsis, thrombocytopenia is a frequent complication and closely associates with increased mortality ${ }^{6,7}$. Whether thrombocytopenia is a marker for more disseminated disease or a contributor to poor outcomes is not known. In the present study, we demonstrate that antibodyinduced thrombocytopenia in mice increases mortality in a 
a

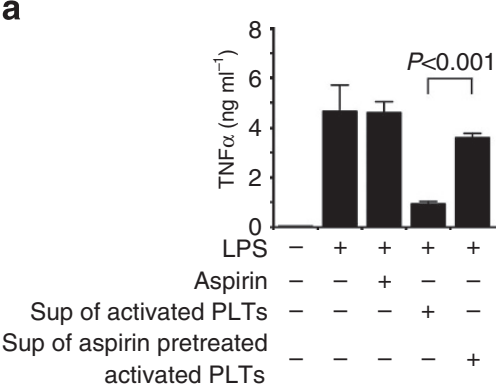

b

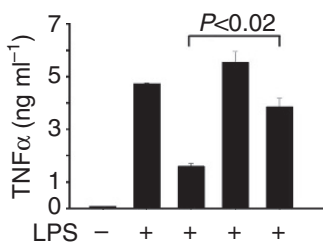

LPS -++++

Sup of resting ${ }_{-}+\ldots+\ldots$

WT PLTS

Sup of Throm-

Activated WT PLTs

Sup of resting

COX1-1-PLTs

Sup of Throm

Activated COX1 $1^{-/-}$PLTs
C

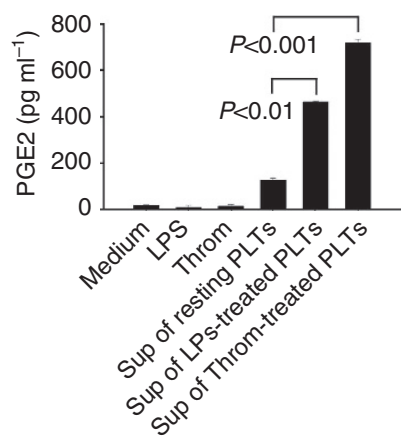

d

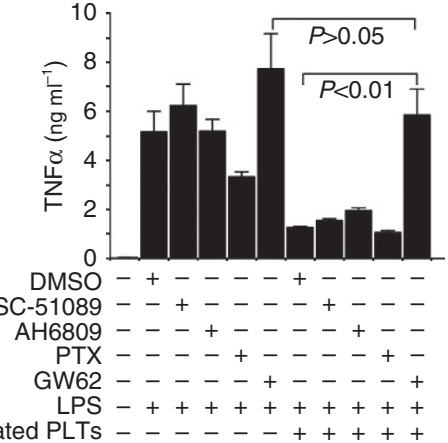

Figure 6 | Platelets inhibit TNF- $\alpha$ production by macrophages through the COX1 signalling pathway. (a) Washed platelets were pre-incubated with aspirin $(1 \mathrm{mM})$ or buffer for $5 \mathrm{~min}$ and then incubated with thrombin in an aggregometer at $37^{\circ} \mathrm{C}$ for 5 min and centrifuged. LPS plus the supernatants of platelets were added to BMDMs and incubated for $6 \mathrm{~h}$. Thrombin or thrombin plus aspirin were added to the wells with LPS in the absence of platelet supernatant as controls. (b) Platelets from COX1 knockout mice (COX1-/-) or wild-type littermates $\left(\mathrm{COX} 1^{+/+}\right)$were incubated with buffer $($resting) or thrombin in an aggregometer at $37^{\circ} \mathrm{C}$ for $5 \mathrm{~min}$. LPS plus the supernatants of platelets were added to BMDMs and incubated for $6 \mathrm{~h}$. (c) Washed platelets from $\mathrm{C} 57 \mathrm{BL} / 6 \mathrm{~J}$ mice were incubated with LPS for $30 \mathrm{~min}$ or thrombin in an aggregometer at $37^{\circ} \mathrm{C}$ for 5 min. $\mathrm{PGE} \mathrm{E}_{2}$ in the supernatant were measured by an enzyme-linked immunosorbent assay (Cayman Chemical, Ann Arbor, MI). (d) BMDMs were pre-incubated with buffer, SC-51089 $10 \mu \mathrm{M}$, AH $680910 \mu \mathrm{M}$, pertusis toxin (PTX) $0.5 \mu \mathrm{g} \mathrm{ml}{ }^{-1}$, or GW627368X (GW62) at $37^{\circ} \mathrm{C}$ for $15 \mathrm{~min}$. BMDMs were then added with LPS or LPS plus supernatant from thrombin-activated platelets and incubated at $37^{\circ} \mathrm{C}$ for $6 \mathrm{~h}$. Values are means \pm s.d. $(n=3$ for all). Differences between two groups were assessed using unpaired two-tailed Student's t-test.

LPS-induced endotoxemia and in a bacterial infusion sepsis model. Depletion of platelets worsened organ injury during septic shock, whereas transfusion of platelets significantly reduced mortality. These findings imply that platelets have a beneficial role in sepsis and protect against septic shock.

TNF- $\alpha$ has a key role in sepsis pathogenesis ${ }^{21,22,25}$. Platelets potentiate macrophage-derived TNF- $\alpha$ production in response to low-dose LPS $\left(\leq 100 \mathrm{pg} \mathrm{ml}^{-1}\right)$ under conditions where TNF- $\alpha$ increased only several fold over the baseline level ${ }^{38,39}$. Platelets also potentiate TNF- $\alpha$ production and inflammation in the mice injected with low-dose LPS $^{40,41}$. Although we observed that platelets enhanced low-dose LPS $\left(1 \mathrm{ng} \mathrm{ml}^{-1}\right)$-elicited TNF- $\alpha$ production, our findings demonstrate that platelets dramatically inhibit high-dose LPS $\left(\geq 10 \mathrm{ng} \mathrm{ml}^{-1}\right)$-induced TNF- $\alpha$ and IL-6 production by macrophages. Platelets also inhibited human macrophage-derived TNF- $\alpha$ production (Supplementary Fig. S4). Therefore, platelets appear to serve as a switch for the inflammatory response during sepsis in that they may promote inflammation at early stage of infection, but inhibit macrophagedependent inflammation when plasma concentrations of LPS are high. Plasma LPS concentration, which can reach several $\mathrm{ng} \mathrm{ml}{ }^{-1}$ to over $100 \mu \mathrm{g} \mathrm{ml}^{-1}$, in severe sepsis carries prognostic significance. High LPS concentrations are associated with increased adverse outcome and higher mortality rate ${ }^{42,43}$.

Plasma IL-6 also predicts mortality in sepsis ${ }^{24,44}$. Although antibiotics decrease the overall mortality of septic mice, all animals with IL-6 levels in plasma $>14.0 \mathrm{ng} \mathrm{ml}^{-1}$ die, regardless of whether they receive antibiotics ${ }^{24}$, suggesting that uncontrolled inflammation is an important cause of mortality. Interestingly, in the bacterial infusion sepsis model, we observed $100 \%$ mortality in control mice (injected with IgG) that had plasma IL-6 concentrations $>14.0 \mathrm{ng} \mathrm{ml}^{-1}$, whereas all of the mice with plasma IL- 6 concentrations $<14.0 \mathrm{ng} \mathrm{ml}^{-1}$ survived. Plasma IL-6 levels in thrombocytopenic mice increased 10- and 29-fold over control animals ( $>63$ and $176 \mathrm{ng} \mathrm{ml}^{-1}$, respectively) at 4 and $8 \mathrm{~h}$ after injection of bacteria. TNF- $\alpha$ concentrations in thrombocytopenic mice increased 77 -fold over controls at $2 \mathrm{~h}$ after injection of bacteria. These data indicate that platelets have an essential role in modulating inflammation during sepsis, and that thrombocytopenia, which often occurs in severe septic patients, may be an important cause for the uncontrolled inflammation and death.

A previous study reported lethal lung haemorrhage in thrombocytopenic mice challenged with $\mathrm{LPS}^{19}$. In that study, the anti-GPIb $\alpha$ monoclonal antibody was injected intravenously, which resulted in a lowering of platelet count to $<2.5 \%$ of that of control mice. They then performed platelet transfusion studies to determine the minimal concentration of platelets that was required for preventing inflammatory bleeding. Platelets from IL $4 \mathrm{R} \alpha / \mathrm{GPIb} \alpha$ transgenic mice, which were resistant to the antiGPIb $\alpha$ antibody, were injected into the inflamed mice. It was found that $10-15 \%$ of normal platelet counts was sufficient to prevent inflammatory bleeding ${ }^{19}$. In our study, thrombocytopenia was elicited by i.p. injection of an anti-GPIb $\alpha$ 

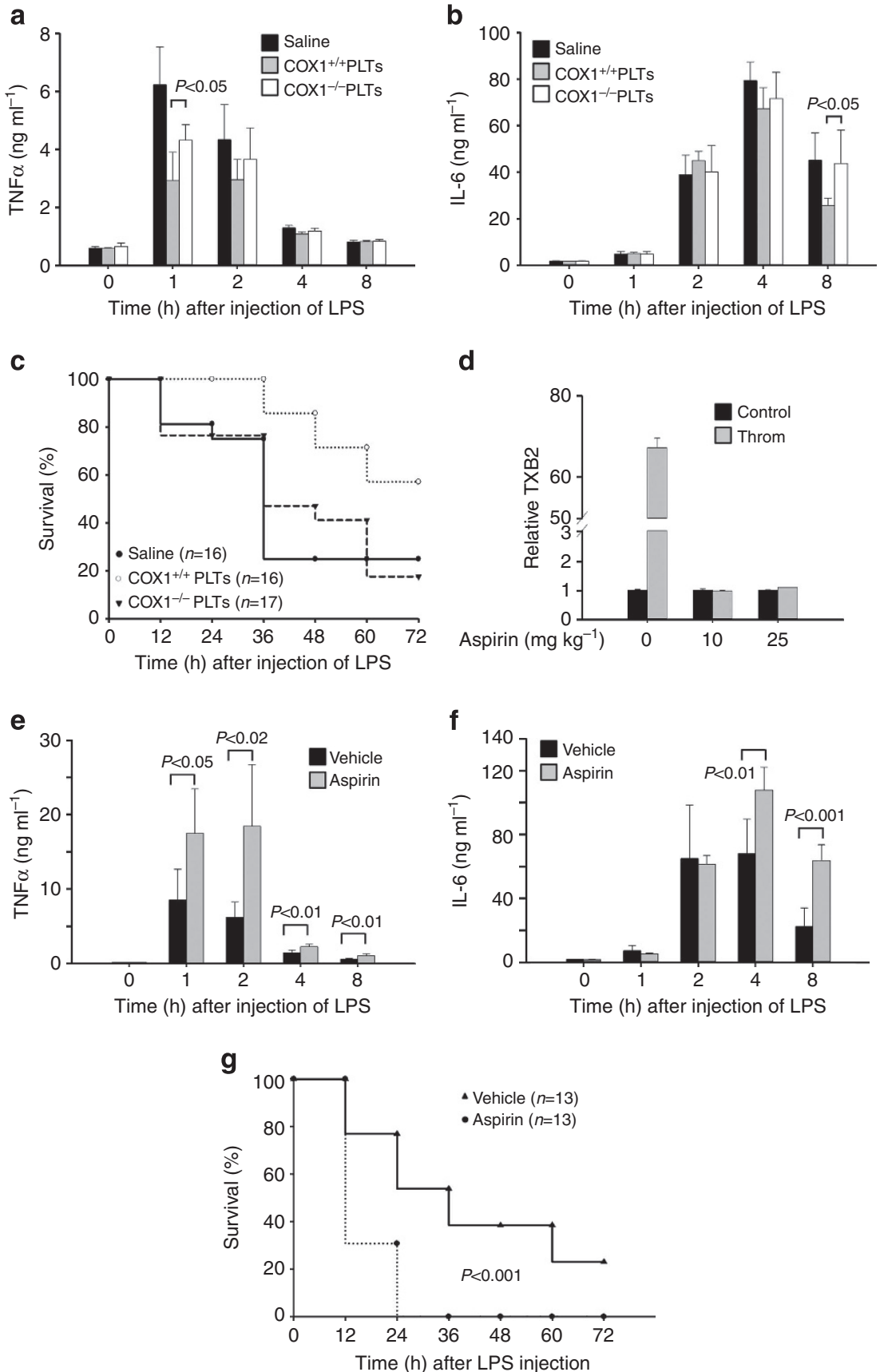

Figure 7 | The effects of COX1 knockout and aspirin on platelet-dependent inhibition of inflammation and protection against sepsis. (a,b) $C 57 \mathrm{BL} / 6$ mice received i.p. injection of LPS $\left(10 \mathrm{mg} \mathrm{kg}^{-1}\right)$, immediately followed by retro-orbital injection of saline or $1 \times 10^{9}$ platelets from COX1-deficient mice $\left(\mathrm{COX}^{-/-}\right)$or wild-type littermates $\left(\mathrm{COX} 1^{+/+}\right)$in $0.2 \mathrm{ml}$ saline. Blood was collected before or at $1,2,4$ and $8 \mathrm{~h}$ after LPS injection. TNF- $\alpha$ (a) and IL-6 (b) concentrations in plasma were measured. Values are means \pm s.d. $(n=5)$. Differences between two groups were assessed using unpaired two-tailed Student's t-test. (c) C57BL/ 6 mice received i.p. injection of LPS $\left(10 \mathrm{mg} \mathrm{kg}^{-1}\right.$ ), immediately followed by retro-orbital injection of $1 \times 10^{9}$ platelets from either COX1 knockout mice or wild-type littermates in $0.2 \mathrm{ml}$ saline or saline. Survival rate was observed for 3 days. $P<0.001$ between control group and the group injected with wild-type platelets; $P>0.2$ between control group and the group injected with COX1-/ - platelets by Wald's test. (d) C57BL/ 6 mice received i.p. injection of aspirin $\left(10\right.$ or $25 \mathrm{mg} \mathrm{kg}^{-1}$ ). Blood was collected at $30 \mathrm{~min}$ after aspirin injection. Washed platelets were incubated with thrombin $\left(0.1 \mathrm{U} \mathrm{ml}^{-1}\right)$ for $5 \mathrm{~min}$, and $\mathrm{TXB}_{2}$ in the supernatant was measured by enzyme-linked immunosorbent assay kit and expressed as relative to platelets from control mice (without aspirin injection) in the absence of thrombin. Values are means \pm s.d. $(n=3)$. Differences between two groups were assessed using unpaired two-tailed Student's t-test. (e,f) C57BL/6 mice received i.p. injection of aspirin ( $\left.25 \mathrm{mg} \mathrm{kg}^{-1}\right) 30 \mathrm{~min}$ before i.p. injection of LPS $\left(10 \mathrm{mg} \mathrm{kg}^{-1}\right)$. Blood was collected before or at 1, 2, 4 and $8 \mathrm{~h}$ after LPS injection. TNF- $\alpha$ (e) and IL-6 (f) concentrations in plasma were measured. Values are means \pm s.d. $(n=6)$. Differences between two groups were assessed using unpaired two-tailed Student's $t$-test. (g) C57BL/ 6 mice received i.p. injection of aspirin $\left(25 \mathrm{mg} \mathrm{kg}^{-1}\right)$ at $30 \mathrm{~min}$ before i.p. injection of LPS $\left(10 \mathrm{mg} \mathrm{kg}^{-1}\right)$. Survival rate was observed for 3 days. $P$-value was calculated by Wald's test in a discrete time hazard model using version 9.2 of SAS software. 
monoclonal antibody, which lowered platelet counts to $\sim 10 \%$ of control. Consistent with previous studies, which reported that platelet counts of $10-15 \%$ normal were sufficient to prevent inflammatory bleeding ${ }^{19,45}$, no significant haemorrhage was observed in the lungs and brains from the thrombocytopenic mice. Therefore, in the present study, the increased mortality from sepsis in thrombocytopenic mice does not appear to be due to inflammatory haemorrhage, but rather to an exacerbated inflammatory response. To reconcile previous findings ${ }^{19,20}$ with our data, we induced thrombocytopenia in mice by retro-orbital injection of the anti-GPIb $\alpha$ antibody. In agreement with the previous studies, retro-orbital injection of the anti-GPIb $\alpha$ antibody induced much severe thrombocytopenia (platelet counts were reduced to $<5 \%$ of that of control mice) and injection of LPS caused severe lung haemorrhage (Supplementary Fig. S5).

Our in-vitro and in vivo data suggest that the beneficial effect of platelets is likely to be due to COX1-dependent generation of $\mathrm{PGE}_{2}$ that acts on macrophage EP4 receptors. $\mathrm{PGE}_{2}$ is a key macrophage modulator ${ }^{36,46-48}$. LPS stimulates COX2 expression and $\mathrm{PGE}_{2}$ production in many cells by upregulating COX2 transcription through NF- $\kappa \mathrm{B}$-dependent pathways ${ }^{37,49,50}$. However, COX1 is the dominant isoform in platelets. Previous studies reported that pretreatment with non-steroidal antiinflammatory drugs enhances endotoxin-induced production of TNF- $\alpha$, IL- 6 and IL- 8 concentrations in the blood of human volunteers ${ }^{51,52}$. Consistent with these findings, aspirin pretreated mice had significantly higher plasma TNF- $\alpha$ and IL-6 concentrations and reduced survival rate than that of control mice in the LPS-induced sepsis model. COX metabolizes arachidonic acid to many biologically active eicosanoids such as prostaglandins, prostacyclins and thromboxane, and both COX1 and COX2 are activated during sepsis. However, they appear to have distinct roles in septic shock. Although aspirin reduced the survival rate in LPS-challenged mice, a COX2-specific inhibitor NS-398 increased the survival rate in LPS-induced endotoxemia ${ }^{53}$, suggesting that in contrast to COX1, COX2derived products aggravate sepsis. Platelet-specific deletion of COX1 or the $\mathrm{PGE}_{2}$ synthase may be helpful in further evaluating the protective role of platelets in septic shock. Our data do suggest that other pathways may also be involved in platelet inhibition of macrophage function, because aspirin or COX1 deficiency only partially reversed platelet inhibition of LPS-induced TNF- $\alpha$ production by macrophages (Fig. 6a,b). In fact, following injection of COX1-deficient platelets, plasma TNF- $\alpha$ concentrations were lower, although to a lesser degree than that observed after injection of wild-type platelets (Fig. 7a). In this regard, a previous study showed that platelet-derived microparticles reduced the release of TNF- $\alpha$ by macrophages activated with LPS $^{54}$

Platelet transfusion has been recommended in septic patients with severe thrombocytopenia, in particular in patients with bleeding or in patients at risk for bleeding ${ }^{55}$. Historically, the purpose of platelet transfusion in sepsis is to halt or prevent bleeding. Our results suggest a potential beneficial effect of platelet transfusion in modulating immune response in sepsis, especially in the severe septic patients. Further studies of platelet transfusion in high-risk sepsis patients may be warranted.

\footnotetext{
Methods

Mice. Mice deficient in $G \alpha_{\mathrm{q}}$ (ref. 29), $\mathrm{P} 2 \mathrm{Y}_{12}$ (ref. 56), $\mathrm{TP}^{57}$, Munc 13-4 (Unc13d $d^{\text {Jinx }}$ mice) ${ }^{35}$, COX1 (ref. 58) and wild-type littermates from heterozygous breeding were used in this study. C57BL/6J mice were purchased from Jackson Laboratories. Mice were bred and maintained in the University of Kentucky Animal Care Facility, following institutional and National Institutes of Health guidelines after approval by the Institutional Animal Care and Use Committee. Eight- to 12-week-old males
} with a variety of genetic manipulations were used in most experiments.
Preparation of mouse platelets. Blood was collected from the abdominal aortas of isoflurane-anaesthetized mice (8-10 weeks) using 1/7 volume of ACD ( $85 \mathrm{mM}$ trisodium citrate, $83 \mathrm{mM}$ dextrose and $21 \mathrm{mM}$ citric acid) as the anticoagulant ${ }^{59}$. Platelets were then washed once with CGS $(0.12 \mathrm{M}$ sodium chloride, $0.0129 \mathrm{M}$ trisodium citrate and $0.03 \mathrm{MD}$-glucose, $\mathrm{pH} 6.5$ ), resuspended in saline at $5 \times 10^{9}$ per $\mathrm{ml}$ for in vivo experiments or in RPMI 1640 medium containing $10 \mathrm{mM}$ HEPES at $3 \times 10^{8}$ per $\mathrm{ml}$ for in-vitro experiments and incubated for $1 \mathrm{~h}$ at $22^{\circ} \mathrm{C}$ before use.

Survival studies. LPS endotoxemia model: male mice (8-10 weeks old) were injected i.p. with $10 \mathrm{mg} \mathrm{kg}^{-1}$ LPS (0111:B4, purchased from Sigma) in a volume of $200 \mu \mathrm{l}$ that was diluted in saline. Survival after LPS challenge was assessed every $12 \mathrm{~h}$ for 3 days. All survived mice were killed at the end of the third day.

Bacterial infusion sepsis model: E. coli ATCC 25922 was grown in Luria broth medium overnight. After washing once with sterile saline, the bacteria were resuspended and diluted in sterile saline. Male mice (8-10 weeks old) were injected i.p. with bacteria in a volume of $200 \mu \mathrm{l}$ saline. Survival after injection of bacteria was assessed every $4 \mathrm{~h}$ for 3 days. All survived mice were killed at the end of the third day.

Platelet depletion and transfusion. Mice were injected i.p. with a commercially available rat antimouse GPIb $\alpha$ monoclonal antibody (Emfret Analytics, Wurzburg, Germany, $4 \mu \mathrm{gg}^{-1}$ body weight) for platelet depletion. Mice were injected with same amount of isotype-matched rat IgG as controls. For platelet counts, mice were bled from the retro-orbital plexus under isoflurane anaesthesia (IsoFlo; Abbott Laboratories, Abbott Park, IL). Blood was collected into a heparin-containing tube and added with $10 \mathrm{mM}$ (final concentration) EDTA as an anticoagulant. Platelet counts in whole blood were analysed with a HEMAVET HV950FS multispecies haematology analyser. For platelet transfusion, $1 \times 10^{9}$ washed platelets resuspended in $0.2 \mathrm{ml}$ saline were injected into the retro-orbital plexus for each recipient mouse.

Macrophage depletion. Mice were injected retro-orbitally with $40 \mathrm{mg} \mathrm{kg}^{-1}$ of liposomal clodronate (L- $\alpha$-Phosphatidyl-choline/cholesterol clodronate; Encapsula NanoSciences, Nashville, TN) at 24 and $4 \mathrm{~h}$, respectively, before being challenged with LPS. The same amount of plain liposomes were injected as control. This method is specific for depletion of monocytes and macrophages, which undergo apoptosis following phagocytosis of the liposomal clodronate. Depletion of monocytes/macrophages was confirmed by flow cytometry analysis. EDTA anticoagulated blood was subjected to red blood cell lysis. White blood cells were resuspended in flow buffer (Hank's balanced salt solution with $0.1 \%$ BSA and $5 \mathrm{mM}$ EDTA) and incubated with Alexa Fluor 488-labelled anti-CD115 and APCCy7-labelled anti-CD45 antibodies.

Isolation of macrophages. Macrophages were isolated from mouse bone marrow and plated in a plastic flask ${ }^{60}$. Bone marrow macrophages were cultured for 7 days in the presence of $15 \%$ conditional medium from L929 cells.

Blood chemistry and cytokine measurements. Aspartate aminotransferase, alanine aminotransferase, $\mathrm{CK}$ and $\mathrm{LDH}$ were measured by Comparative Clinical Pathology Services (Columbia, MO). TNF- $\alpha$ and IL- 6 were measured by ELISA assay (eBioscience, San Diego, CA). To observe the effects of platelets on TNF- $\alpha$ and IL-6 production in macrophages, washed platelets or medium were incubated with LPS $\left(100 \mathrm{ng} \mathrm{ml}^{-1}\right.$ ) for $30 \mathrm{~min}$ and added to $2 \times 10^{5}$ macrophages precoated in 96-well plates. To observe the effects of platelet releasates on TNF- $\alpha$ and IL-6 production in macrophages, washed platelets were incubated with LPS $\left(100 \mathrm{ng} \mathrm{ml}^{-1}\right)$ at room temperature for $30 \mathrm{~min}$ or thrombin $\left(0.1 \mathrm{U} \mathrm{ml}^{-1}\right)$ in an aggregometer with stirring at 1,000 r.p.m. at $37^{\circ} \mathrm{C}$ for $5 \mathrm{~min}$ and then centrifuged at 2,500 r.p.m. at $22^{\circ} \mathrm{C}$ for $3 \mathrm{~min}$. Supernatants from LPS- or thrombin-stimulated platelets were added with LPS to 96 -well plates precoated with $2 \times 10^{5}$ macrophages per well and incubated at $37^{\circ} \mathrm{C}$ for $6 \mathrm{~h}$.

Histologic examination. Mice were injected i.p. with an antimouse GPIb $\alpha$ monoclonal antibody or control IgG. After $4 \mathrm{~h}$, LPS $\left(10 \mathrm{mg} \mathrm{kg}^{-1}\right)$ was injected i.p. Mice were anaesthetized and the lungs and brains were isolated at $15 \mathrm{~h}$ after injection of LPS. The lungs and brains were fixed with $4 \%$ paraformaldehyde in $0.1 \mathrm{~m}$ phosphate buffer ( $\mathrm{pH} 7.4$ ) for 2 days at $4{ }^{\circ} \mathrm{C}$ and then processed to paraffin embedding. Sections were cut at $5 \mu \mathrm{m}$ and stained by haematoxylin and eosin. Images were captured with a Leica DM IRB microscope using $\times 20$ objective (Leica Microsystems, Wetzlar, Germany).

Statistical analyses. The survival assay was analysed by Wald's test in a discrete time hazard model using version 9.2 of SAS software. Significance in experiments comparing two groups was examined by unpaired two-tailed Student's $t$-test. Values are reported as the mean \pm s.d. A value of $P<0.05$ was considered significant. 


\section{References}

1. Semple, J. W., Italiano, Jr. J. E. \& Freedman, J. Platelets and the immune continuum. Nat. Rev. Immunol. 11, 264-274 (2011).

2. Li, Z., Yang, F., Dunn, S., Gross, A. K. \& Smyth, S. S. Platelets as immune mediators: their role in host defense responses and sepsis. Thromb. Res. 127, 184-188 (2011)

3. Russwurm, S. et al. Platelet and leukocyte activation correlate with the severity of septic organ dysfunction. Shock 17, 263-268 (2002).

4. Levi, M. Platelets in sepsis. Hematology 10(Suppl 1): 129-131 (2005).

5. Akca, S. et al. Time course of platelet counts in critically ill patients. Crit. Care Med. 30, 753-756 (2002).

6. Sharma, B. et al. Thrombocytopenia in septic shock patients-a prospective observational study of incidence, risk factors and correlation with clinical outcome. Anaesth. Intens. Care 35, 874-880 (2007).

7. Moreau, D. et al. Platelet count decline: an early prognostic marker in critically ill patients with prolonged ICU stays. Chest 131, 1735-1741 (2007).

8. Andonegui, G. et al. Platelets express functional Toll-like receptor-4. Blood 106, 2417-2423 (2005).

9. Clark, S. R. et al. Platelet TLR4 activates neutrophil extracellular traps to ensnare bacteria in septic blood. Nat. Med. 13, 463-469 (2007).

10. Ma, A. C. \& Kubes, P. Platelets, neutrophils, and neutrophil extracellular traps (NETs) in sepsis. J. Thromb. Haemost. 6, 415-420 (2008).

11. Evangelista, V. et al. Src family kinases mediate neutrophil adhesion to adherent platelets. Blood 109, 2461-2469 (2007).

12. Vieira-de-Abreu, A., Campbell, R. A., Weyrich, A. S. \& Zimmerman, G. A. Platelets: versatile effector cells in hemostasis, inflammation, and the immune continuum. Semin. Immunopathol. 34, 5-30 (2012).

13. Weyrich, A. S., McIntyre, T. M., McEver, R. P., Prescott, S. M. \& Zimmerman, G. A. Monocyte tethering by $\mathrm{P}$-selectin regulates monocyte chemotactic protein-1 and tumor necrosis factor-alpha secretion. Signal integration and NF-kappa B translocation. J. Clin. Invest. 95, 2297-2303 (1995).

14. Weyrich, A. S. et al. Activated platelets signal chemokine synthesis by human monocytes. J. Clin. Invest. 97, 1525-1534 (1996).

15. Dixon, D. A. et al. Expression of COX-2 in platelet-monocyte interactions occurs via combinatorial regulation involving adhesion and cytokine signaling. J. Clin. Invest. 116, 2727-2738 (2006).

16. Blair, P. \& Flaumenhaft, R. Platelet alpha-granules: basic biology and clinical correlates. Blood Rev. 23, 177-189 (2009).

17. Cloutier, N. et al. Platelets can enhance vascular permeability. Blood 120, 1334-1343 (2012)

18. Doi, K., Leelahavanichkul, A., Yuen, P. S. \& Star, R. A. Animal models of sepsis and sepsis-induced kidney injury. J. Clin. Invest. 119, 2868-2878 (2009).

19. Goerge, T. et al. Inflammation induces hemorrhage in thrombocytopenia. Blood 111, 4958-4964 (2008)

20. Boulaftali, Y. et al. Platelet ITAM signaling is critical for vascular integrity in inflammation. J. Clin. Invest. 123, 908-916 (2013).

21. Tracey, K. J. \& Cerami, A. Tumor necrosis factor: a pleiotropic cytokine and therapeutic target. Annu. Rev. Med. 45, 491-503 (1994).

22. Parameswaran, N. \& Patial, S. Tumor necrosis factor-alpha signaling in macrophages. Crit. Rev. Eukaryot. Gene Expr. 20, 87-103 (2010).

23. Kruttgen, A. \& Rose-John, S. Interleukin-6 in sepsis and capillary leakage syndrome. J. Interferon Cytokine Res. 32, 60-65 (2012).

24. Turnbull, I. R. et al. Antibiotics improve survival in sepsis independent of injury severity but do not change mortality in mice with markedly elevated interleukin 6 levels. Shock 21, 121-125 (2004)

25. Pfeffer, K. et al. Mice deficient for the $55 \mathrm{kd}$ tumor necrosis factor receptor are resistant to endotoxic shock, yet succumb to L. monocytogenes infection. Cell 73, 457-467 (1993)

26. Flynn, J. L. et al. Tumor necrosis factor-alpha is required in the protective immune response against Mycobacterium tuberculosis in mice. Immunity 2, 561-572 (1995)

27. Esmon, C. T. et al. Inflammation, sepsis, and coagulation. Haematologica $\mathbf{8 4}$, 254-259 (1999).

28. Levi, M., van der Poll, T. \& Schultz, M. Systemic versus localized coagulation activation contributing to organ failure in critically ill patients. Semin. Immunopathol. 34, 167-179 (2012).

29. Offermanns, S., Toombs, C. F., Hu, Y. H. \& Simon, M. I. Defective platelet activation in G alpha(q)-deficient mice. Nature 389, 183-186 (1997).

30. Ren, Q., Ye, S. \& Whiteheart, S. W. The platelet release reaction: just when you thought platelet secretion was simple. Curr. Opin. Hematol. 15, 537-541 (2008)

31. Shashkin, P. N., Brown, G. T., Ghosh, A., Marathe, G. K. \& McIntyre, T. M Lipopolysaccharide is a direct agonist for platelet RNA splicing. J. Immunol. 181, 3495-3502 (2008).

32. Cognasse, F. et al. Toll-like receptor 4 ligand can differentially modulate the release of cytokines by human platelets. Br. J. Haematol. 141, 84-91 (2008).
33. Zhang, G. et al. Lipopolysaccharide stimulates platelet secretion and potentiates platelet aggregation via TLR4/MyD88 and the cGMP-dependent protein kinase pathway. J. Immunol. 182, 7997-8004 (2009).

34. Kahner, B. N., Shankar, H., Murugappan, S., Prasad, G. L. \& Kunapuli, S. P. Nucleotide receptor signaling in platelets. J. Thromb. Haemost. 4, 2317-2326 (2006).

35. Ren, Q. et al. Munc13-4 is a limiting factor in the pathway required for platelet granule release and hemostasis. Blood 116, 869-877 (2010).

36. Strassmann, G., Patil-Koota, V., Finkelman, F., Fong, M. \& Kambayashi, T. Evidence for the involvement of interleukin 10 in the differential deactivation of murine peritoneal macrophages by prostaglandin E2. J. Exp. Med. 180, 2365-2370 (1994).

37. Wu, D. \& Meydani, S. N. Mechanism of age-associated up-regulation in macrophage PGE2 synthesis. Brain. Behav. Immun. 18, 487-494 (2004).

38. Aiura, K. et al. Interaction with autologous platelets multiplies interleukin-1 and tumor necrosis factor production in mononuclear cells. J. Infect. Dis. 175, 123-129 (1997).

39. Scull, C. M., Hays, W. D. \& Fischer, T. H. Macrophage pro-inflammatory cytokine secretion is enhanced following interaction with autologous platelets. J. Inflamm. (Lond.) 7, 53 (2010).

40. Aslam, R. et al. Platelet Toll-like receptor expression modulates lipopolysaccharide-induced thrombocytopenia and tumor necrosis factor-alpha production in vivo. Blood 107, 637-641 (2006).

41. Looney, M. R. et al. Platelet depletion and aspirin treatment protect mice in a two-event model of transfusion-related acute lung injury. J. Clin. Invest. 119, 3450-3461 (2009).

42. Opal, S. M. et al. Relationship between plasma levels of lipopolysaccharide (LPS) and LPS-binding protein in patients with severe sepsis and septic shock J. Infect. Dis. 180, 1584-1589 (1999).

43. Behre, G. et al. Endotoxin concentration in neutropenic patients with suspected gram-negative sepsis: correlation with clinical outcome and determination of anti-endotoxin core antibodies during therapy with polyclonal immunoglobulin M-enriched immunoglobulins. Antimicrob. Agents Chemother. 36, 2139-2146 (1992).

44. Remick, D. G., Bolgos, G. R., Siddiqui, J., Shin, J. \& Nemzek, J. A. Six at six: interleukin-6 measured $6 \mathrm{~h}$ after the initiation of sepsis predicts mortality over 3 days. Shock 17, 463-467 (2002).

45. Loria, G. D., Romagnoli, P. A., Moseley, N. B., Rucavado, A. \& Altman, J. D. Platelets support a protective immune response to LCMV by preventing splenic necrosis. Blood 121, 940-950 (2013).

46. Xu, X. J., Reichner, J. S., Mastrofrancesco, B., Henry, Jr. W. L. \& Albina, J. E. Prostaglandin E2 suppresses lipopolysaccharide-stimulated IFN-beta production. J. Immunol. 180, 2125-2131 (2008).

47. Sakamoto, A., Matsumura, J., Mii, S., Gotoh, Y. \& Ogawa, R. A prostaglandin E2 receptor subtype EP4 agonist attenuates cardiovascular depression in endotoxin shock by inhibiting inflammatory cytokines and nitric oxide production. Shock 22, 76-81 (2004).

48. Nemeth, K. et al. Bone marrow stromal cells attenuate sepsis via prostaglandin $\mathrm{E}(2)$-dependent reprogramming of host macrophages to increase their interleukin-10 production. Nat. Med. 15, 42-49 (2009).

49. D'Acquisto, F. et al. Involvement of NF-kappaB in the regulation of cyclooxygenase-2 protein expression in LPS-stimulated J774 macrophages. FEBS Lett. 418, 175-178 (1997).

50. Abate, A., Oberle, S. \& Schroder, H. Lipopolysaccharide-induced expression of cyclooxygenase- 2 in mouse macrophages is inhibited by chloromethylketones and a direct inhibitor of NF-kappa B translocation. Prostaglandins Other Lipid Mediat. 56, 277-290 (1998).

51. Martich, G. D., Danner, R. L., Ceska, M. \& Suffredini, A. F. Detection of interleukin 8 and tumor necrosis factor in normal humans after intravenous endotoxin: the effect of antiinflammatory agents. J. Exp. Med. 173, 1021-1024 (1991).

52. Spinas, G. A., Bloesch, D., Keller, U., Zimmerli, W. \& Cammisuli, S. Pretreatment with ibuprofen augments circulating tumor necrosis factor-alpha, interleukin-6, and elastase during acute endotoxinemia. J. Infect. Dis. 163 89-95 (1991)

53. Reddy, R. C. et al. Selective inhibition of COX-2 improves early survival in murine endotoxemia but not in bacterial peritonitis. Am. J. Physiol. Lung Cell Mol. Physiol. 281, L537-L543 (2001).

54. Sadallah, S., Eken, C., Martin, P. J. \& Schifferli, J. A. Microparticles (ectosomes) shed by stored human platelets downregulate macrophages and modify the development of dendritic cells. J. Immunol. 186, 6543-6552 (2011).

55. Zimmerman, J. L. Use of blood products in sepsis: an evidence-based review. Crit. Care Med. 32, S542-S547 (2004).

56. Foster, C. J. et al. Molecular identification and characterization of the platelet ADP receptor targeted by thienopyridine antithrombotic drugs. J. Clin. Invest. 107, 1591-1598 (2001).

57. Thomas, D. W. et al. Coagulation defects and altered hemodynamic responses in mice lacking receptors for thromboxane A2. J. Clin. Invest. 102, 1994-2001 (1998). 
58. Langenbach, R. et al. Prostaglandin synthase 1 gene disruption in mice reduces arachidonic acid-induced inflammation and indomethacin-induced gastric ulceration. Cell 83, 483-492 (1995).

59. Zhang, G. et al. Distinct roles for Rap1b protein in platelet secretion and integrin alphaIIbbeta3 outside-in signaling. J. Biol. Chem. 286, 39466-39477 (2011).

60. Davies, J. Q. \& Gordon, S. Isolation and culture of murine macrophages. Methods Mol. Biol. 290, 91-103 (2005).

\section{Acknowledgements}

This work was supported by the American Heart Association Midwest Affiliate Grant-inAid 0855698 G (to Z.L.) and in part supported by the American Society of Hematology (ASH) bridge Grant Award and the NIH/National Center for Research Resources Centers of Biomedical Research Excellence in Obesity and Cardiovascular Disease Grant P20 RR021954. B.X. is a recipient of the American Heart Association Postdoctoral Fellowship Award. This work was support in part by resources provided by the Lexington VA Medical Center. We thank Dr. Richard Charnigo for his assistance with statistical analysis and Dr. Wendy S. Katz for her technical support for the histologic analysis. We thank Dr. Prabhakara R. Nagareddy and Judy F. Glass for their assistance with detection of monocyte depletion by flow cytometry.

\section{Authors contributions}

B.X. and Z.L. designed the research; Z.L. supervised the study; B.X. and G.Z. carried out most of the experiments; L.G. and X.-A.L. carried out some experiments of in vivo sepsis model; S.W.W. provided Jinx mice and helped with the analysis of secretion data; A.J.M. helped with PGE2 measurement; A.J.M., A.D. and S.S.S. provided extra technical assistance; S.S.S. provided valuable suggestions; B.X., A.D., S.S.S. and Z.L. wrote the manuscript. All authors commented on the manuscript.

\section{Additional information}

Supplementary Information accompanies this paper at http://www.nature.com/ naturecommunications

Competing financial interests: The authors declare no competing financial interests.

Reprints and permission information is available online at http://npg.nature.com/ reprintsandpermissions/

How to cite this article: Xiang, B. et al. Platelets protect from septic shock by inhibiting macrophage-dependent inflammation via the cyclooxygenase 1 signalling pathway. Nat. Commun. 4:2657 doi: 10.1038/ncomms3657 (2013). 